\title{
Invasive solid papillary carcinoma with invasive lobular and invasive breast carcinoma, no special type: a rare association
}

\author{
Rashim Sharma, ${ }^{1}$ Balamurugan Thirunavukkarasu (D) ,' Poonam Elhence, ${ }^{1}$ \\ Jeewan Ram Vishnoi (D) ${ }^{2}$
}

${ }^{1}$ Pathology and Lab Medicine, All India Institute of Medical Sciences Jodhpur, Jodhpur, Rajasthan, India ${ }^{2}$ Surgical Oncology, All India Institute of Medical Sciences Jodhpur, Jodhpur, Rajasthan, India

Correspondence to

Dr Balamurugan

Thirunavukkarasu

bala.potter@gmail.com

Accepted 4 May 2021
Check for updates

(c) BMJ Publishing Group Limited 2021. No commercial re-use. See rights and permissions. Published by BMJ.

\footnotetext{
To cite: Sharma $R_{\text {, }}$

Thirunavukkarasu B,

Elhence $\mathrm{P}$, et al. BMJ Case

Rep 2021;14:e243628.

doi:10.1136/bcr-2021-

243628
}

\section{DESCRIPTION}

A 38-year-old woman visited a breast clinic with a history of lumpectomy in the left breast. Mammography prior to lumpectomy showed Breast Imaging Reporting and Database System (BI-RADS) 4b lesion in the upper outer quadrant of the left breast measuring $5.5 \times 3.5 \times 3 \mathrm{~cm}$. Before proceeding with a definitive therapy, the paraffin blocks were reviewed. Histopathological examination showed solid tumour nodules separated by fibrovascular cores with the periphery of tumour showing ragged contours in a desmoplastic stroma imparting a jig-saw pattern occupying $70 \%$ of the tissue. The cells were bland looking with low-grade atypia (figure $1 \mathrm{~A}-\mathrm{C}$ ). The adjacent area showed tumour cells arranged as clusters and tubules (figure 1D) as well as cords and single-file pattern (figure 1E) (10\% each) and foci of lobular carcinoma in situ (LCIS) (5\%). P63 immunostain was negative at the periphery of the tumour nodules, confirming a

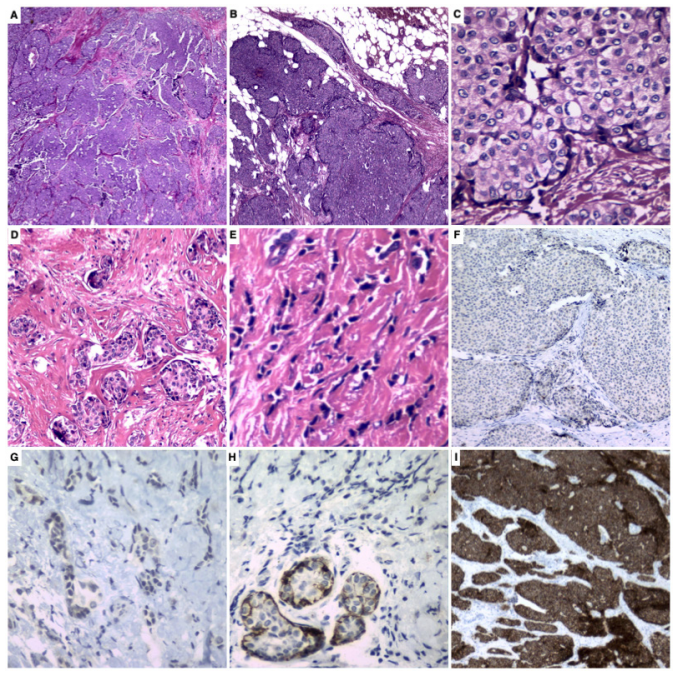

Figure 1 (A-C) Solid papillary carcinoma. (A) Tumour arranged as solid nodules separated by thin fibrovascular septae $(\times 40)$. (B) Ragged infiltrative edges of tumour into the adjacent parenchyma $(\times 40)$. (C) Low-grade nuclear atypia (×200). (D) Invasive carcinoma of no special type (NST) arranged as tubules in a desmoplastic stroma $(\times 40)$. (E) Invasive lobular carcinoma arranged as cords and single-file pattern $(\times 200)$. $(F, G)$ p63 loss in the solid papillary carcinoma and invasive carcinoma, NST, respectively $(\times 100)$. $(\mathrm{H}) \mathrm{E}$-cadherin loss in the invasive lobular component with retention in the periphery of lobular carcinoma in situ $(\times 200)$. (I) E-cadherin retained in the solid papillary carcinoma $(\times 40)$. diagnosis of solid papillary carcinoma (SPC) and invasive breast carcinoma of no special type (IBC-NST) (figure $1 \mathrm{~F}, \mathrm{G}$ ). E-cadherin was retained in the invasive solid papillary component and NST while lost in the invasive lobular component (ILC) (figure 1H,I). No extracellular mucin was seen. Chromogranin was negative. Ancillary studies showed a luminal type A phenotype with ER, PgR positivity and negative HER2. Ki-67 labelling index was 10\%. A final diagnosis of an invasive SPC (70\%) with conventional IBC-NST type (10\%) and ILC (10\%) was rendered. The invasive component had Nottingham histological grade 2 (glandular (acinar)/tubular differentiation: score 2, nuclear pleomorphism: score 2, mitotic rate: score 2 (6/10 High power field (hpf); Filed Diameter (FD): $0.5 \mathrm{~mm})$ ). The patient underwent breast conservative surgery (BCS) with axillary dissection at our institute as the margins of the previous surgery were positive. Axillary lymph node dissection was done as per institute protocol since clinically few lymph nodes were enlarged and as there was a dominant invasive component. Residual tumour nodules of SPC were identified along with LCIS. Metastatic carcinoma was identified in 2 out of 21 lymph nodes which showed solid deposit with focal ductal differentiation (pathological stage pT3N1).

SPC was first reported by Maluf and Koerner in $1995 .{ }^{1}$ It is a rare breast carcinoma usually reported in postmenopausal women accounting for $<1 \%$ of all breast cancers. It has an excellent prognosis with less propensity for lymph node metastasis, local recurrence and distant metastasis, and thus, wide local excision or BCS with or without axillary dissection and adjuvant treatment is the preferred treatment. SPC can coexist with other invasive carcinomas like colloid carcinoma, tubular carcinoma, lobular carcinoma and the conventional type and thereby changing the treatment from a conservative to more aggressive approach. This 3 -in-1 combination has been described in literature by Nassar et al in 2006 and Tan et al in 2016. ${ }^{23}$ The present case underscores the multifaceted nature of SPC and significance of sampling of tumour with judicious application of immunohistochemistry.

\section{Patient's perspective}

Sacrifice of one's own organ due to cancer is traumatizing, but being aware of benefits of surgery, correct diagnosis and a structured treatment is what brings quality of life back. 


\section{Learning points}

Solid papillary carcinoma can have other coexisting invasive carcinoma like lobular and no special type.

- Treatment modality and the prognosis of these solid papillary carcinoma vary and thus must be determined based on the other invasive components.

- The specimen should be grossed thoroughly and individual component should be identified with the help of immunohistochemistry.

Contributors All the authors were involved in conception, design and approval of the work. RS and BT were involved in design, data collection and drafting. BT, PE and $\mathrm{JRV}$ were involved in data analysis and approval.

Funding The authors have not declared a specific grant for this research from any funding agency in the public, commercial or not-for-profit sectors.
Competing interests None declared.

Patient consent for publication Obtained.

Provenance and peer review Not commissioned; externally peer reviewed.

\section{ORCID iDs}

Balamurugan Thirunavukkarasu http://orcid.org/0000-0002-5583-1720 Jeewan Ram Vishnoi http://orcid.org/0000-0003-1484-8929

\section{REFERENCES}

1 Maluf HM, Koerner FC. Solid papillary carcinoma of the breast. A form of intraductal carcinoma with endocrine differentiation frequently associated with mucinous carcinoma. Am J Surg Pathol 1995; 19:1237-44.

2 Nassar H, Qureshi H, Adsay NV, et al. Clinicopathologic analysis of solid papillary carcinoma of the breast and associated invasive carcinomas. Am J Surg Pathol 2006:30:501-7.

3 Tan BY, Thike AA, Ellis 10, et al. Clinicopathologic characteristics of solid papillary carcinoma of the breast. Am J Surg Pathol 2016;40:1334-42.

Copyright 2021 BMJ Publishing Group. All rights reserved. For permission to reuse any of this content visit

https://www.bmj.com/company/products-services/rights-and-licensing/permissions/

BMJ Case Report Fellows may re-use this article for personal use and teaching without any further permission.

Become a Fellow of BMJ Case Reports today and you can:

Submit as many cases as you like

- Enjoy fast sympathetic peer review and rapid publication of accepted articles

- Access all the published articles

Re-use any of the published material for personal use and teaching without further permission

Customer Service

If you have any further queries about your subscription, please contact our customer services team on +44 (0) 2071111105 or via email at support@bmj.com.

Visit casereports.bmj.com for more articles like this and to become a Fellow 